\title{
PELATIHAN PENENTUAN HARGA POKOK PRODUKSI UNTUK MENCAPAI BREAK EFENT POINT (BEP) OPTIMAL PADA WALI MURID PENGELOLA UMKM DI PAUD BINA BANGSA DESA JATISARI KECAMATAN SENORI KABUPATEN TUBAN
}

\author{
Hidayatul Khusnah ${ }^{1}$, Mardiyah Anugraini ${ }^{2}$ \\ Prodi Akuntani Fakultas Ekonomi Bisnis dan Teknologi Digital Universitas Nahdlatul Ulama Surabaya \\ Hidayatul.khusnah@unusa.ac.id
}

\begin{abstract}
Abstrak
Kegiatan pengabdian pada masyarakat ini dilakukan untuk meningkatkan perbaikan taraf hidup dan kesejahteraan jangka panjang bagi pengelola UMKM yang ada di desa Jatisari Kecamatan Senori Kabupaten Tuban. Kegiatan ini akan dilaksanakan secara luring dengan tetap menerapkan protokol kesehatan dengan ketat. Kegiatan ini akan diikuti oleh wali murid PAUD Bina Bangsa Desa jatisari Kecamatan Senori yang memiliki UMKM. Permaslahan utama para pengelola UMKM adalah minimnya pengetahuan tentang cara penentuan harga pokok produksi dari produk mereka. Pada dasarnya penentuan harga pokok produksi itu adalah salah satu hal yang penting bagi para pelaku usaha, jika mereka tidak memahami dan mengetahui cara menghitung yang benar maka usahanya tidak dapat berkembang dengan pesat. Berdasarkan hal di atas, maka kami berinisiatif untuk melakukan pelatihan penentuan harga pokok produksi untuk mencapai break efent point (bep) optimal, dengan harapan dapat membantu para pelaku usaha agar dapat meningkatkan usahanya. Kemudian untuk melihat perubahan pola laporan keuangan ukm maka setelah selesai pelaksanaan intervensi sosialisasi pengabdian masyarakat, langkah akhir adalah melakukan evaluasi. Evaluasi dirancang dengan membandingkan kondisi pengetahuan dan kesadaran awal sebelum intervensi sosialisasi dengan peningkatan pengetahuan dan kesadaran setelah pelaksanaan intervensi. Pemotretan pengetahuan dan kesadaran perangkat dan guru tentang laporan keuangan lembaga pendidikan, dengan menggunakan kuesioner individu yang berupa pre test dan post test.
\end{abstract}

Kata Kunci: Harga Pokok Produksi, UMKM, Break event point 


\section{PENDAHULUAN}

Usaha Mikro Kecil dan Menengah (UMKM) telah diakui sangat strategis dan penting tidak hanya bagi pertumbuhan ekonomi tetapi juga untuk pembagian pendapatan yang merata. Karena peranannya yang sangat strategis dan penting, Indonesia memberikan perhatian khusus bagi perkembangan-perkembangan mereka, termasuk membina lingkungan dengan iklim usaha yang kondusif, memfasilitasi dan memberikan akses pada sumber daya produktif dan memperkuat kewirausahaan serta daya saingnya.

Berdasarkan rencana strategis Kementerian Koperasi Dan Usaha Kecil Dan Menengah Republik Indonesia Tahun 2010 - 2014 dalam kurun waktu 5 tahun ke depan, Koperasi dan UMKM masih akan menghadapi banyak kendala. Kelembagaan usaha Koperasi dan UMKM merupakan aspek penting yang perlu dicermati dalam membedah permasalahan Koperasi dan UMKM.

Perlu digaris bawahi bahwa lebih dan 51 juta usaha yang ada, atau lebih dan 99,9\% pelaku usaha adalah Usaha Mikro dan Kecil, dengan skala usaha yang sulit berkembang karena tidak mencapai skala usaha yang ekonomis. Dengan badan usaha perorangan, kebanyakan usaha dikelola secara tertutup, dengan Legalitas usaha dan administrasi kelembagaan yang sangat tidak memadai. Upaya pemberdayaan UMKM makin rumit karena jumlah dan jangkauan UMKM demikian banyak dan luas, terlebih bagi daerah tertinggal, terisolir dan perbatasan.

UMKM juga menghadapi persoalan rendahnya kualitas sumberdaya manusia. Kebanyakan SDM UMKM berpendidikan rendah dengan keahlian teknis, kompetensi, kewirausahaan dan manajemen yang seadanya. Langkah perubahannya dapat dilakukan dalam berbagai bentuk kebijakan kurikulum dan pelaksanaan diklat serta revitatisasi lembaga diklat. Hal ini perlu disadari sedari dini, karena sebagai penopang penciptaan wirausaha baru, jumlah dan keberadaan lembaga pengembangan usaha, Lembaga diklat dan inkubator sangat sedikit dan jauh dan memadai.

Masalah klasik lain yang dihadapi Koperasi

dan UMKM adalah terbatasnya akses UMKM kepada sumberdaya produktif. Akses kepada sumberdaya produktif terutama terhadap bahan baku, permodalan, teknologi, sarana pemasaran serta informasi pasar. Berkaitan dengan akses teknologi, kebanyakan Koperasi dan UMKM mengunakan teknologi sederhana, kurang memanfaatkan teknologi yang lebih memberikan nilai tambah produk. Demikian juga Koperasi dan UMKM sulit untuk memanfaatkan informasi pengembangan produk dan usahanya. Upaya pemberdayaannya juga diliputi dengan adanya ketimpangan dalam penguasaan sumberdaya produktif baik antar pelaku usaha, antar daerah maupun antara pusat dan daerah.

Kegiatan ini akan dilaksanakan secara luring dengan tetap menerapkan protokol kesehatan dengan ketat. Kegiatan ini akan diikuti oleh wali murid PAUD Bina Bangsa Desa jatisari Kecamatan Senori yang memiliki UMKM. Desa Jatisari adalah desa dengan produk utama hasil pertanian, akan tetapi masayarakat di sana memiliki tekat yang kuat untuk berwirausaha. Usaha mereka beraneka ragam, mulai dari usaha krupuk puli, usaha tempe, usaha marning, usaha keripik temped an lain-lain. permaslahan utama mereka adalah kurangnya wawasan dan pengetahuan terkait dengan bagaimana cara menentukan harga pokok produksi yang tepat untuk setiap produknya masih sangat rendah. Pada dasarnya penentuan harga pokok produksi itu adalah salah satu hal yang penting bagi para pelaku usaha, jika mereka tidak memahami dan mengetahui cara menghitung yang benar maka usahanya tidak dapat berkembang dengan pesat.

Efek berikutnya jika para pelaku usaha tidak mengetahui cara penghitungan harga pokok produksi yang tepat adalah usaha yang jalan ditempat bahkan kebangkrutan. Hal tersebut terjadi karena pelaku usaha menentukan harga produknya hanya berdasarkan kira-kira saja, atau bahkan hanya ikut harga di pasar, tidak berdasarkan penghitungan yang tepat. Berdasarkan hal tersebut, maka berinisiatif untuk melakukan pelatihan penentuan harga pokok produksi untuk mencapai break efent point (bep) optimal, dengan harapan dapat membantu para pelaku usaha agar dapat meningkatkan usaha dan menghidarkan mereka dari kebangkrutan.

Permasalahan yang dialami oleh mitra diantaranya adalah rendahnya kualitas sumberdaya 
manusia. Kebanyakan SDM UMKM berpendidikan rendah dengan keahlian teknis, kompetensi, kewirausahaan dan manajemen yang seadanya. Permasalahan lebih rincinya salah satunya adalah belum adanya pengetahuan terkait dengan penentuan harga pokok produksi, sehingga para pelaku usaha tidak memiliki patokan yang baku untuk menentukan harga jual dari produk yang mereka hasilkan. Ketidakmampuan para pelaku usaha untuk menentukan harga jual yang optimal akan berimbas pada perolehan laba yang optimal. Apabila perolehan laba tidak optimal dapat menyebabkan lambatnya dalam mencapai BEP.

\section{METODE}

Metode pelaksanaan kegiatan pegabdian kepada masyarakat ini dilakukan dengan tatap muka secara langsung dengan menerapkan protokol kesehatan dengan ketat. Pelatihan dilakukan di gedung PAUD Bina Bangsa Desa jatisari Kecamatan Senori Kabupaten Tuban. Pelatihan dilakukan sekali dalam satu semester, dan pendampingan dilakukan dua minggu setelah pelatihan. Pendampingan ini ada dua macam, yakni pendampingan rutin dan pendampingan incidental. Pendampingan rutin dilakukan setiap 2 minggu sekali, sedangkan pendampingan incidental akan dilakukan setiap ada pembukaan program-program yang berbasis kewirausahaan di buka. Proses pendampingan akan dilakukan oleh tutor sebaya, yaitu peserta yang dianggap sudah mammpu menyusun HPP dan BEP sehingga dapat membantu peserta lain yang masih belum mampu

\section{HASIL DAN PEMBAHASAN}

Adapun hasil yang dicapai setelah selesainya Program Pengabdian kepada Masyarakat EFBTD Universitas Nahdlatul Ulama Surabaya ini diharapkan mampu menyelesaikan permasalahan yang dialami oleh pengelola atau pemilik UMKM di desa jatisari kecamatan senori kabupaten tuban. Pertama Peningkatan pengembangan ilmu dan teknologi perguruan tinggi melalui pelatihan penghitungan dan penyusunan harga pokok produksi pada pengelola UMKM, pelatihan dan pendampingan pembuatan catatan dan laporan keuangan. Dari kegiatan pelatihan dan pendampingan ini diharapkan mitra dapat mengelola usahanya dengan baik dan dapat menciptakan produk yang mempunyai daya saing dengan kompetitor serta dapat diterima dipasar luas, serta dapat mengelola keuangannya sebaik mungkin. Kedua Peningkatan pengetahuan serta kemampuan dalam menyusun laporan keuangan usaha dengan baik dan benar

\section{KESIMPULAN}

Program pelatihan penentuan harga pokok produksi kepada Ibu-Ibu pengelola UMKM di desa jatisari kecamatan senori kabupaten tuban dapat diselenggarakan dengan baik dan berjalan dengan lancar sesuai dengan rencana kegiatan yang telah disusun meskipun belum semua peserta pelatihan menguasai dengan baik materi yang disampaikan. Kegiatan ini mendapat sambutan sangat baik terbukti dengan keaktifan peserta mengikuti pendampingan dengan tidak meninggalkan tempat sebelum waktu pelatihan berakhir.

\section{UCAPAN TERIMAKASIH}

Ucapan terima kasih kami sampaikan ke kepada Lembaga Penelitian dan Pengabdian Masyarakat Universitas Nahdlatul ulama Surabaya yang telah mendanai serta memberi support luar biasa sehingga kegiatan ini dapat terlaksana dengan lancar.

\section{REFERENSI}

De Porter, Bobbi dan Hernacki, Mike. 1992. Quantum Learning. Membiasakan Belajar Nyaman dan Menyenangkan. Terjemahan oleh Alwiyah Abdurrahman. Bandung: Penerbit Kaifa.

Sujimat, D. Agus. 2000. Penulisan karya ilmiah. Makalah disampaikan pada pelatihan penelitian bagi guru SLTP 
Negeri di Kabupaten Sidoarjo tanggal 19 Oktober 2000 (Tidak diterbitkan). MKKS SLTP Negeri Kabupaten Sidoarjo

Suparno. 2000. Langkah-langkah Penulisan Artikel Ilmiah dalamSaukah, Ali dan Waseso, M.G. 2000. Menulis Artikel untuk Jurnal Ilmiah. Malang: UM Press.
Wahab, Abdul dan Lestari, Lies Amin. 1999. Menulis Karya Ilmiah. Surabaya: Airlangga University Press.

Winardi, Gunawan. 2002. Panduan Mempersiapkan Tulisan Ilmiah. Bandung: Akatiga. 